\title{
SUITABILITY OF POLYVINYL WASTE POWDER AS PARTIAL REPLACEMENT FOR CEMENT IN CONCRETE PRODUCTION
}

\author{
E. Ikponmwosa ${ }^{1,}$, , C. Fapohunda ${ }^{2}$ and S. Ehikhuenmen ${ }^{3}$ \\ 1,3 DEPARTMENT OF CIVIL AND ENVIRONMENTAL ENGINEERING, UNIVERSITY OF LAGOS, LAGOS. NIGERIA \\ 2DEPARTMENT OF BUILDING, CALEB UNIVERSITY, IMOTA, LAGOS, NIGERIA \\ E-mail addresses: ${ }^{1}$ eikponmwosa@unilag.edu.ng,2 fapohunda07@yahoo.com,3ehisam.can@gmail.com
}

\begin{abstract}
This work presents the results of investigation conducted to assess the suitability of polyvinyl waste powder (PWP) as partial replacement of cement in the production of concrete. Up to 50\% by weight of cement was replaced with PWP at interval of 10\%. The parameters investigated are: the chemical composition of polyvinyl waste powder (PWP) and the setting times of cement-polyvinyl paste. Also investigated in concrete containing polyvinyl powder were: workability, density, compressive strength, and tensile strength. The results showed that polyvinyl waste powder (PWP) has a pozzolanic effect by the consideration of strength activity index, and higher compressive strength than the control specimens for replacement level up to 20\%, and up to $30 \%$ cement resulted in higher splitting strength. Further inclusion of polyvinyl waste powder (PWP) increased the setting times of cement-PWP paste, and resulted in a reduction in concrete workability as the replacement value of cement with PWP increased. From these results, it can be concluded that polyvinyl waste powder (PWP) is suitable as partial replacement of cement at the replacement levels considered in the current investigation.
\end{abstract}

Keywords: Compressive Strength, Polyvinyl Waste Powder, Pozzolanic, Tensile Strength, Workability.

\section{INTRODUCTION}

The importance of concrete in the building and construction of myriads of infrastructure to nurture, drive, and sustain the present civilisation cannot be overemphasised. With the global annual production at over 11.5 billion tonnes [1], concrete is the world most consumed man-made material [2]. Critical to concrete production is the cement, which serves as the major binder that binds the constituents' materials together. However, in developing countries, especially Nigeria, meeting the cement needs is becoming impossible. With the annual cement needs put at 19.5 million tonnes [3], more than $10 \%$ of her annual budget will be needed to meet the cement needs alone [4]. There is thus an urgent need to find a suitable substitute, either to fully replace or to partially replace cement in the production of concrete. Researchers have since been looking into the areas of wastes industrial, construction, agricultural, etc - for possible solution, by way of determining their suitability or otherwise as substitute for cement in concrete production. For example, Baboo et al. [5] investigated into the possibility of using marble powder to partially replace cement in the production of concrete. They found out that the inclusion of marble powder improved the concrete with respect to workability, compressive strength and flexural strength. However, [6] later concluded that the improved performance occurred at cement replacement levels up to $16 \%$. The results of investigation conducted by $[7,8]$ on the possibility of using saw dust ash as partial replacement of cement showed that saw dust ash has beneficial effect on concrete when curing for longer duration. The works of [9] on partially replacing cement with rice husk ash revealed an improved concrete if the replacement level is not above $10 \%$. Others efforts include the works of [10] on cassava peel ash, $[4,11,12,13]$ on pulverised bone, and [14] on aluminium roofing sheet waste, etc. The present work investigates possibility of using polyvinyl waste powder (PWP) as partial replacement of cement in the production of concrete. Polyvinyl are materials made from polymers of vinyl compounds, which are subsequently used to manufacture building materials 
(roofing sheets, windows, vinyl siding), consumer products, disposable packaging, and many every day products [15]. According to [16], annual generation of polyvinyl waste powder (PWP) stands at about 12 million tonnes. He further concluded that these wastes pose a serious environmental threat because of the fact that they are difficult to dispose and recycle. Thus the aim of this work is to find out to what extent polyvinyl wastes powder (PWP) can be used in production of concrete. The parameters investigated to achieve this aim include: chemical properties, setting times, workability, compressive strength, tensile strength.

\section{MATERIALS AND METHODS}

\subsection{Materials}

To carry out the investigation, the following materials were used, namely: cement, fine aggregates, coarse aggregates, and water. Polyvinyl waste powder (PWP) was used as partial replacement of cement by weight. The ordinary Portland cement was produced in accordance to $[17,18]$. The fine aggregates were river sand obtained from Ogun River located at Ibafo in Ogun State, Nigeria. The particle sizes of sand were those passing through sieve with aperture size of 3.35 $\mathrm{mm}$ but retained on sieves of $63 \mu \mathrm{m}$. It was confirmed to be salt free and free from deleterious substances. The coarse aggregates used in this research study were granite chippings with particle size range between $5 \mathrm{~mm}$ and $20 \mathrm{~mm}$. The polyvinyl waste powder (PWP) was obtained from the dumping site of Nigerite Limited Ikeja, Nigeria, a polyvinyl-based roofing sheet manufacturing company. The waste was milled to fine powder, and was stored in a cool place. Portable water which was fresh, colourless, odourless and free of organic matter was used in these experiments. For the purpose of this investigation, a mix ratio of 1:2:4 by weight of cement, sand and gravel was used, and the water cement ratio of 0.65 was adopted. The cement in the mix was partially replaced with PWP at interval of $10 \%$ up to $50 \%$. The concrete with $0 \% \mathrm{PW}$ replacement served as the control.

\subsection{Laboratory Tests}

\subsubsection{Physical and Chemical Analysis of Materials}

Laboratory tests carried out on the aggregates include particle size distribution, specific gravity, dry and bulk densities, and moisture contents. In order to determine the chemical constituents of Polyvinyl waste powder (PWP), samples were taken and subjected to analysis using the combination of Spectrophotometer, Atomic Absorption Spectrophotometer and Gravimetric methods at the Department of Chemistry, University of Lagos, Nigeria.

\subsubsection{Setting Times Tests}

The setting times (initial and final) were carried out in accordance with [18], using the Vicat probe and the Vicat needle apparatus. The cement content of the paste was partially replaced with polyvinyl waste powder (PWP) at different cement replacement levels of $10 \%, 20 \%, 30 \%, 40 \%, 50 \%$. The paste without PWP served as the control.

\subsubsection{Workability Test}

The slump test was carried out in accordance with the provisions of [19]. The replacement was done at the interval of $10 \%$ up to $50 \%$ cement replacement with Polyvinyl waste powder (PWP).

The sample without PWP serves as the control.

\subsubsection{Density and Compressive Strength Tests}

Density and Compressive strength tests were conducted on $150 \times 150 \times 150$ cube specimens, respectively in accordance with [20,21]. A total of 60 numbers of $150 \times 150 \times 150$ cube specimens were prepared. All the cubes specimens were cured by immersion in water right from the moment they were removed from the moulds - 24 hours after casting until the day for their testing when they were removed from the curing water tank and sun dried before being tested for strength. Density and compressive strength tests were carried out on the cube specimens at curing age of 7, 14, 21, and 28 days. For density and compressive strength tests, the cement was replaced with Polyvinyl waste powder (PWP) up to $40 \%$ at interval of $10 \%$. The limit of $40 \%$ cement replacement with PW was determined from the result of the initial and final setting times. The weight of each cube was taken prior to compressive strength test, and was used to calculate the density.

\subsubsection{Tensile Strength Test}

In order to assess the tensile characteristics of concrete samples with Polyvinyl waste powder (PWP) as partial replacement of cement, the splitting tensile strength was conducted on $150 \times 150 \times 300$ concrete cylinder specimens in accordance with the provision [22]. Figure 1 shows the testing arrangement.

The splitting strengths were determined on $600 \mathrm{KN}$ Avery Denison Universal Testing machine at a loading rate of $120 \mathrm{KN} / \mathrm{min}$ until failure. 


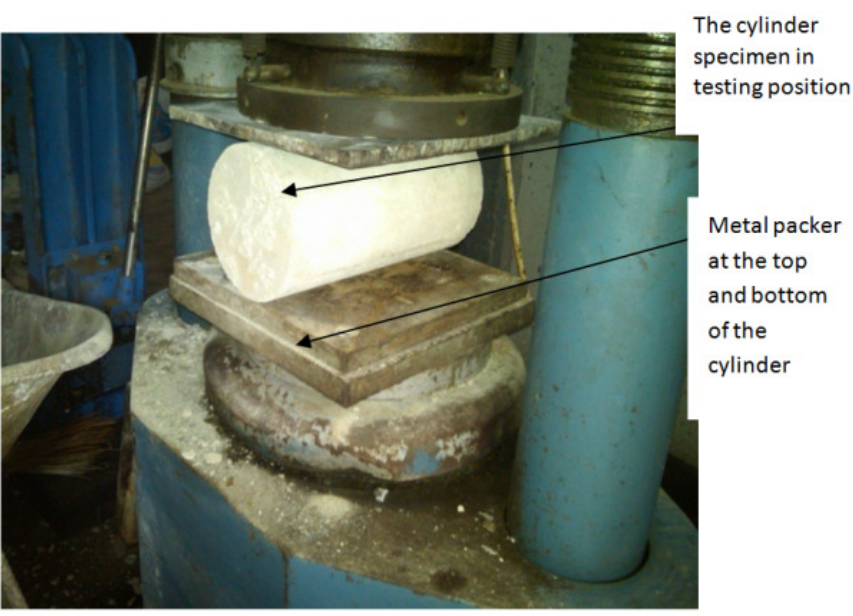

Figure 1: Splitting Test Specimens

The splitting tensile strength (Ts) is then calculated as follows:

$$
T_{s}=\frac{2 P}{\pi l d}
$$

In (1) Ts is the splitting tensile strength $\left(\mathrm{N} / \mathrm{mm}^{2}\right), \mathrm{P}$ is the maximum applied load (in Newtons) by the testing machine, $l$ is the length of the specimen ( $\mathrm{mm}$ and $\mathrm{d}$ is the diameter of the specimen $(\mathrm{mm})$

\section{RESULTS AND DISCUSSIONS}

\subsection{Physical Properties}

The physical properties of materials used in this investigation are presented in Table 1.
From Table 1, it can be observed that the fineness of the polyvinyl waste powder (PWP) was comparable with that of cement, however the PWP was lighter than the cement from the result of the bulk density. What this means is that more volume of PWP will be required for a unit weight of cement replaced. The moisture content of PWP was however found to be higher than that of cement. What this suggest is possible increase in water/binder ratio of the mix, which will likely result in lower compressive strength development. Also from the results of the sieve analysis conducted for the sand and coarse aggregates, the computed coefficient of uniformity $\left(\mathrm{C}_{\mathrm{u}}\right.$ $\left.=\frac{D_{60}}{D_{10}}\right)$ and coefficient of curvature $\left(\mathrm{C}_{\mathrm{c}}=\frac{D_{30} \times D_{30}}{D_{60} D_{10}}\right)$ of the sand were respectively 1.42 and 1.41 ; and for the coarse aggregates were respectively 1.50 and 1.50 . Also the fineness modulus was 0.95 . As these values fall within the range considered for good quality concrete production [23], it can be thus be concluded that both the sand and coarse aggregates were well graded and suitable for concrete production.

\subsection{The Chemical Constitution of Polyvinyl waste powder (PWP)}

The result of chemical analysis conducted to determine the chemical composition of polyvinyl waste powder (PWP) is presented in Table 2,

From Table 2, it can be seen that the composition of major oxides $\left(\mathrm{SiO}_{2}, \mathrm{CaO}\right.$, and $\left.\mathrm{Al}_{2} \mathrm{O}_{3}\right)$ in both the ordinary Portland cement and the Polyvinyl waste powder (PWP) are comparable.

Table 1: Physical Properties of the materials Used

\begin{tabular}{lcccc}
\hline \multicolumn{1}{c}{ Physical Properties } & Sand & Coarse Aggregates & Cement & Polyvinyl waste powder (PWP) \\
\hline Fineness (passing through $600 \mu m)$ & - & - & 99.5 & 75 \\
Dry Density $\left(\mathrm{kg} / \mathrm{m}^{3}\right)$ & 1405.1 & 1403.29 & - & 698.44 \\
Bulk Density $\left(\mathrm{kg} / \mathrm{m}^{3}\right)$ & 1409.55 & 1407.36 & 1297.79 & 839.25 \\
Specific Gravity & 2.63 & 2.66 & 3.15 & 2.47 \\
Moisture Content $(\%)$ & 0.323 & 0.29 & - & 20.16 \\
Coefficient of Uniformity $\left(\mathrm{C}_{\mathrm{u}}\right)$ & 1.42 & 1.50 & - & - \\
Coefficient of Curvature $\left(\mathrm{C}_{\mathrm{c}}\right)$ & 1.41 & 1.50 & - & - \\
\hline
\end{tabular}

Table 2: The Chemical Composition of Polyvinyl waste powder (PWP)

\begin{tabular}{cccc}
\hline & Compounds & Ordinary Portland Cement & Polyvinyl waste powder (PWP) \\
\hline 1 & $\mathrm{SiO}_{2}$ & 18.34 & 19.18 \\
2 & $\mathrm{CaO}$ & 63.97 & 63.30 \\
3 & $\mathrm{Al}_{2} \mathrm{O}_{3}$ & 4.73 & 3.90 \\
4 & $\mathrm{Na}_{2} \mathrm{O}$ & 0.55 & 0.75 \\
5 & $\mathrm{~K}_{2} \mathrm{O}$ & 0.48 & 0.46 \\
6 & $\mathrm{MgO}$ & 2.16 & 2.25 \\
7 & $\mathrm{Fe}_{2} \mathrm{O}_{3}$ & 0.38 & 2.40 \\
8 & $\mathrm{SO}_{3}$ & 0.51 & 1.44 \\
9 & $\mathrm{H}_{2} \mathrm{O}$ & 0.006 & 0.08 \\
10 & $\mathrm{BaO}$ & 0.02 & 0.03 \\
11 & Loss on Ignition & 0.11 & 2.32 \\
\hline
\end{tabular}


Also the loss on ignition, a measure of the extent of carbonation and hydration of free magnesia due to atmospheric exposure for cement and polyvinyl waste powder (PWP) are less than $3 \%$ as set by [18]. In addition, the alkalis $\mathrm{K}_{2} \mathrm{O}$ and $\mathrm{Na}_{2} \mathrm{O}$ with combined percentages of $1.03 \%$ and $1.21 \%$ for both cement and polyvinyl waste powder (PWP) are low, thus reducing the risk of possible destructive alkali-aggregate reactions [24]. Both materials are however free of cyanide which causes corrosion of reinforcement.

\subsection{Effect of Polyvinyl on Setting Times}

The effect of polyvinyl waste powder (PWP) on the initial and final setting times of paste is shown in Figure 3.

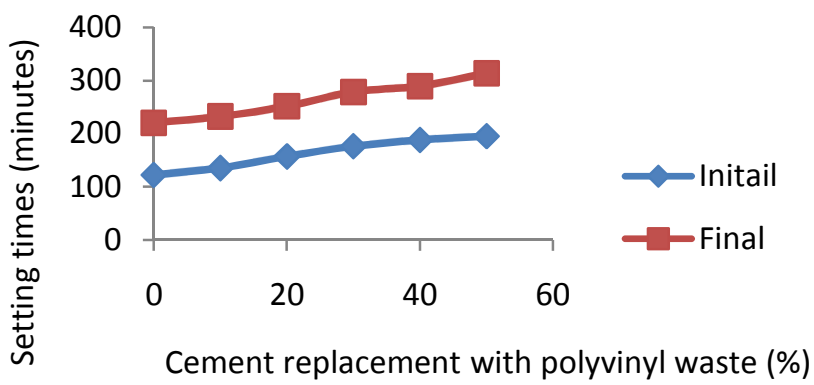

Figure 3: Effect of Polyvinyl waste powder (PWP) on the Setting Time of Cement Paste

From figure 3, it can be observed that both the initial and the final setting times of paste incorporating polyvinyl waste powder (PWP) increased as the amount of cement replacement with polyvinyl waste powder (PWP) increased, in a linear pattern. In order words, polyvinyl waste powder (PWP) inhibits cement hydration in paste incorporating it, thus acting as a retarder. This retarding property may be advantageous in hot weather concreting, or in road construction where concrete will have to be transported over long distance. However, for practical purposes, cement replacement with polyvinyl waste powder (PWP) of $40 \%$ (with the final setting time of 280 minutes) can be considered suitable for strength development required for formwork removal.

\subsection{Effect of Polyvinyl on Workability}

At all the replacement levels considered, the specimens displayed a true slump. This is an indication that inclusion of polyvinyl waste powder (PWP) in the mix has no effect on the cohesiveness of the mix to the extent of causing shear or collapse slump. The effects of polyvinyl waste powder (PWP) on the workability of the concrete, measured in terms of loss of slump, are shown in Figure 4.

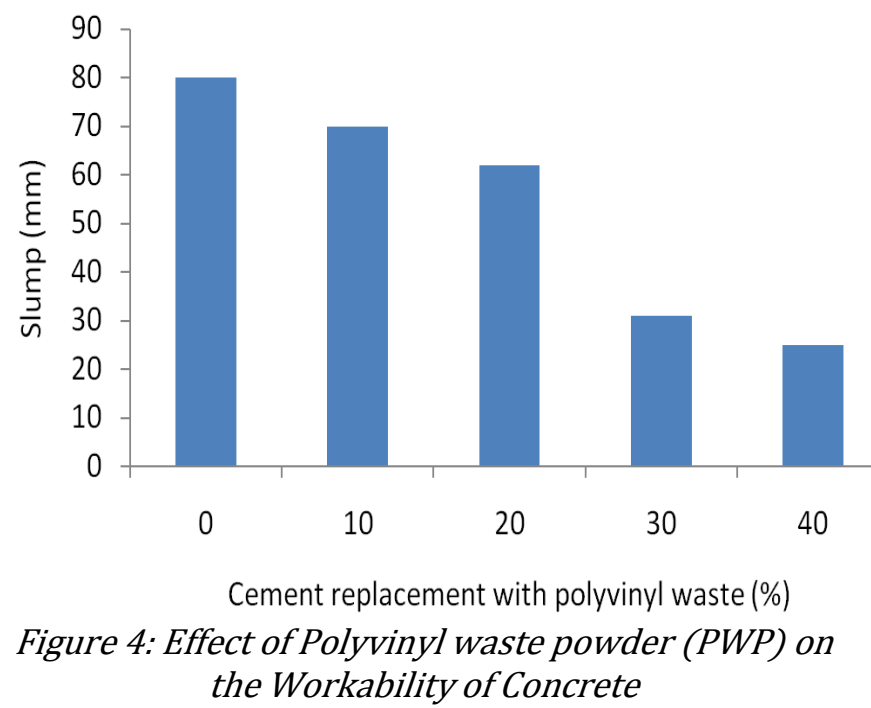

The figure shows gradual decrease in slump as the percent replacement of cement with polyvinyl waste powder (PWP) increased. This behaviour suggests a dehydrating effect of polyvinyl waste powder (PWP) on the concrete matrix. This finding is in line with results obtained earlier (Table 1) in which PWP was found to be finer than cement, a phenomenon that will give rise to higher surface area, and thus more water demand. The consequence of this behaviour is that, it may result in the reduction of the amount of water available for hydration for the purpose of strength formation, leading to relatively reduced strength development. Thus in using polyvinyl waste powder (PWP) for concrete production, a higher water/binder ratio may be desired. Using the guide given by [24], the description of workabilities according to the magnitude of the observed slump in this study is given in Table 3 .

Table 3: Description of Workability of Concrete incorporating Polyvinyl waste powder (PWP)

\begin{tabular}{ccc}
\hline \% Replacement & $\begin{array}{c}\text { Slump Value } \\
(\mathrm{mm})\end{array}$ & Workability [24] \\
\hline 0 & 80 & High \\
10 & 70 & High \\
20 & 62 & High \\
30 & 30 & Low \\
40 & 25 & Low \\
\hline
\end{tabular}

Cement replacement with polyvinyl waste powder (PWP) up to $20 \%$ by weight will result in high workability. That is, up to $20 \%$ cement replacement with polyvinyl waste powder (PWP), the ease with which the resulting fresh concrete can be mixed, placed, and consolidated and finished to a homogeneous condition is high [25]. Beyond 20\% cement replacement with polyvinyl waste powder (PWP), the workability of the resulting fresh concrete is low, which may lead to harsh mixes, thus leading to lack of cohesion in the mix [24]. 


\subsection{Effect of Polyvinyl on Density}

The effect of polyvinyl waste powder (PWP) on the density of the concrete specimens is shown in Figure 5 .
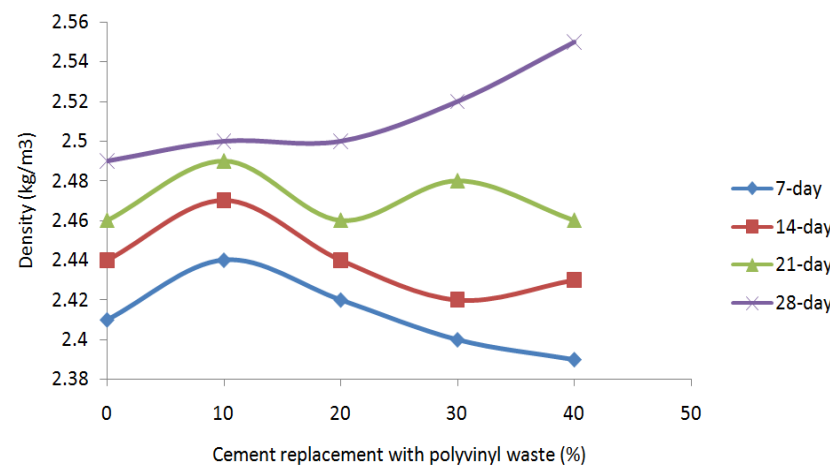

-14 -day

\pm 21 -day

$\leftarrow 28$-day

Figure 5: Effect of Polyvinyl waste powder (PWP) on the Density of Concrete Specimens

From figure 5, no definite trend was observed at all the cement replacement with polyvinyl waste powder (PWP) until 28 days of curing. The $28^{\text {th }}$ day density of the specimens increased as the cement replacement with polyvinyl waste powder (PWP) increased. This could only mean that progressive inclusion of polyvinyl waste powder (PWP) in the mix resulted in the densification of the matrix only at the "structural age" of 28 days curing. The fact that the polyvinyl waste powder (PWP) was finer (Table 1) than the cement could also contribute to the higher density as a result of more closely packed inner matrix. The variation of density of concrete with curing age is shown in Figure 6. It can be seen that the densities increased with curing ages at all cement replacement with polyvinyl waste powder (PWP). Also, the numerical values of all the densities at all replacement values were in the density range for normal concrete of between $2200-2550 \mathrm{~kg} / \mathrm{m}^{3}$ [26].

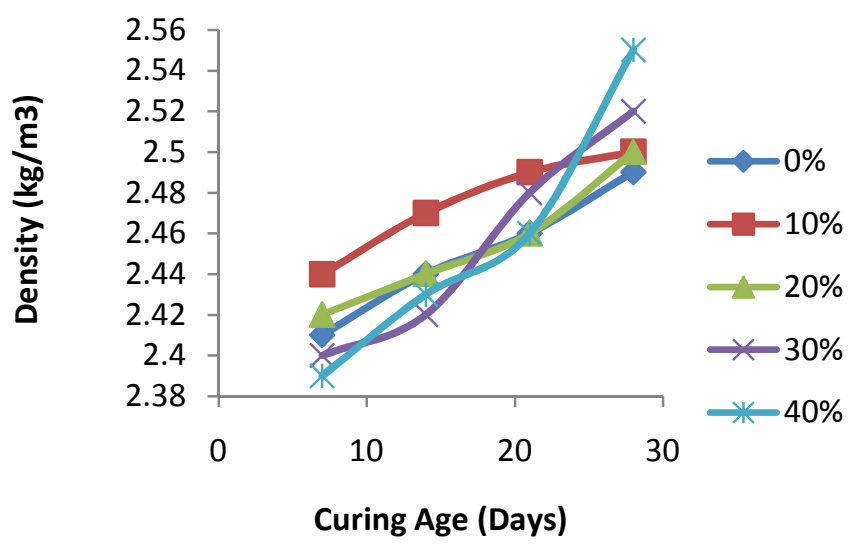

Figure 6: Variation of Density of Concrete incorporating Polyvinyl waste powder (PWP) with Curing Age
This means that the use of polyvinyl waste in concrete production will result in normal weight concrete.

\subsection{Effect of Polyvinyl on Compressive Strength}

The effects of polyvinyl waste powder on the compressive strength of concrete are shown in Figures 7 and 8.

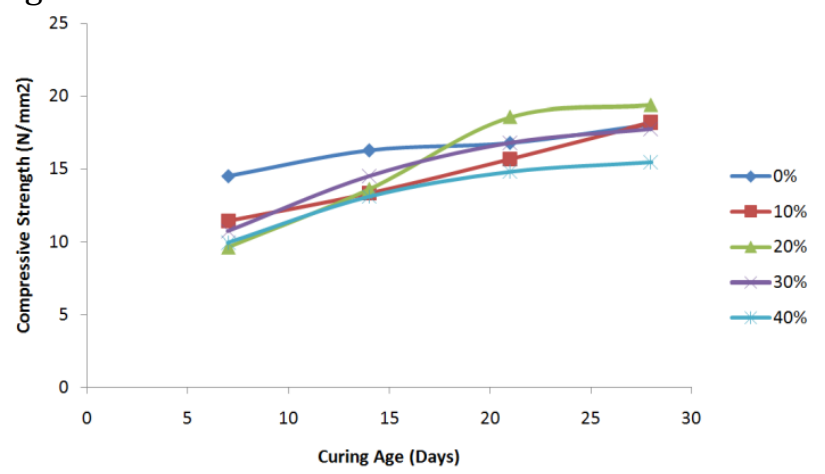

Figure 7: Variation of Strength with Curing Ages for Concrete incorporating Polyvinyl waste powder (PWP)

From figure 7, it can be observed that the compressive strength increased with curing ages for all the specimens at all cement replacement with polyvinyl waste powder (PWP). This can be attributed to the continued formation of the strength-forming C-S-H gel, resulting from hydration as the curing age increased. From Figure 8 however, it can further be observed that the compressive strength decreased as the quantity of the polyvinyl waste powder (PWP) in the mix increased especially at the early ages of curing.

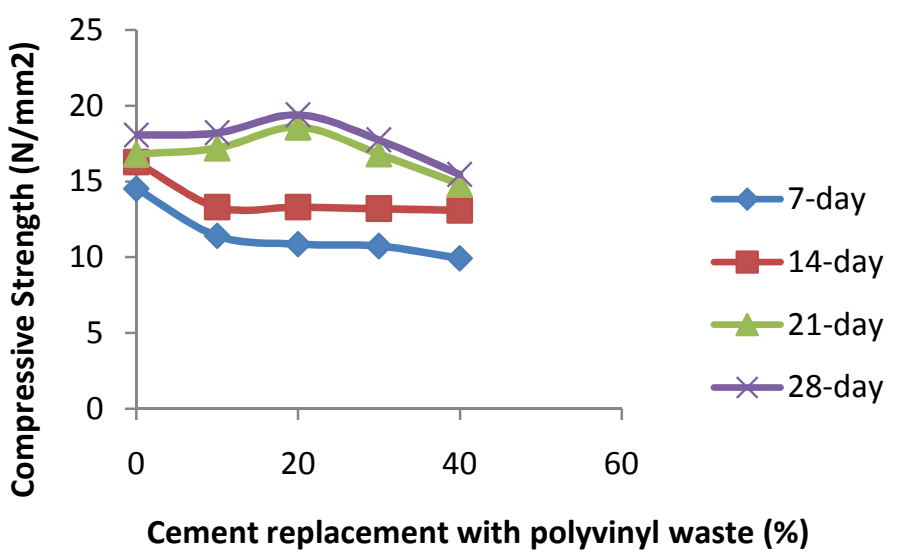

Figure 8: Effect of Polyvinyl waste powder (PWP) on the Compressive Strength of Concrete

However, beginning from $21^{\text {st }}$ day of curing, increase in the cement replacement with polyvinyl waste resulted in increase in the compressive strength up to $20 \%$ replacement level. It is also to be noted that the $28^{\text {th }}$ day strength of $10 \%$ and $20 \%$ cement replacement with polyvinyl waste were higher than the control. In other words, there was strength improvement in the specimens for replacement up to $20 \%$. 
Table 4: Determination of the Pozzolanicity of Polyvinyl waste powder (PWP) through Strength Activity Index (SAI)

\begin{tabular}{|c|c|c|c|c|c|c|c|c|}
\hline \multirow[t]{4}{*}{$\%$ of (PWP) in the Mix } & \multicolumn{8}{|c|}{ Compressive Strength , CS $\left(\mathrm{N} / \mathrm{mm}^{2}\right)$ and Strength Activity Index, SAI } \\
\hline & \multicolumn{8}{|c|}{ Curing Ages (days) } \\
\hline & \multicolumn{2}{|c|}{7} & \multicolumn{2}{|c|}{14} & \multicolumn{2}{|c|}{21} & \multicolumn{2}{|c|}{28} \\
\hline & $\begin{array}{c}\mathrm{CS} \\
\left(\mathrm{N} / \mathrm{mm}^{2}\right)\end{array}$ & SAI (\%) & $\begin{array}{c}\mathrm{CS} \\
\left(\mathrm{N} / \mathrm{mm}^{2}\right)\end{array}$ & SAI (\%) & $\begin{array}{c}\mathrm{CS} \\
\left(\mathrm{N} / \mathrm{mm}^{2}\right)\end{array}$ & SAI (\%) & $\begin{array}{c}\mathrm{CS} \\
\left(\mathrm{N} / \mathrm{mm}^{2}\right)\end{array}$ & SAI (\%) \\
\hline 0 & 14.52 & 100 & 16.29 & 100 & 16.80 & 100 & 18.08 & 100 \\
\hline 10 & 11.41 & 78.60 & 13.33 & 81.83 & 15.70 & 93.45 & 18.22 & 100.07 \\
\hline 20 & 9.63 & 66.30 & 13.63 & 83.67 & 18.59 & 110.65 & 19.41 & 107.36 \\
\hline 30 & 10.74 & 74.00 & 14.52 & 89.13 & 16.81 & 100.00 & 17.76 & 93.23 \\
\hline 40 & 9.93 & 68.39 & 13.11 & 80.48 & 14.82 & 88.21 & 15.48 & 85.62 \\
\hline
\end{tabular}

The computation of pozzolanicity of polyvinyl waste powder (PWP) through Strength activity index (SAI) is shown in Table 4.

The strength activity index is measured by calculating the strength developed by the blend of the suspected pozzolan relative to the control. For any material to be classified as a pozzolan, the strength of the blended sample at 7-day and/or 28-day must not be less than the $75 \%$ of the strength of control specimens [27].

From Table 4, it can be seen that at 7-day only the sample with $10 \%$ of cement replaced with polyvinyl waste powder (PWP) met the criterion of pozzolanicity. However, at 28-day curing, all the mixes exhibited pozzolanic traits because the 28-day strengths of specimens containing polyvinyl waste powder (PWP) were all more than $75 \%$ of the strength of specimens without polyvinyl waste powder (PWP), that is, the control specimens. It can thus be concluded that polyvinyl is pozzolanic as per [27].

\subsection{Effect of Polyvinyl on Tensile Strength}

The results of the tensile strength of concrete incorporating polyvinyl waste powder (PWP), measured through the splitting tensile strength are presented in Figures 9 and 10. From Figure 9, it can be observed that the splitting strength increased with increase in cement replacement with PWP up to $30 \%$, suggesting enhanced tensile strength with the usage of PWP. This trend was observed for all the curing ages.

Also, as can be seen in Figure 10, the tensile strength increased with increase in curing age at all the replacement levels. The $28^{\text {th }}$ day relationship between the splitting tensile strength and compressive strength expressed as a ratio is presented in Table 5 .

From Table 5, it can be observed that the ratio of splitting tensile strength to compressive strength improved with the percent increase in polyvinyl waste in the mix.

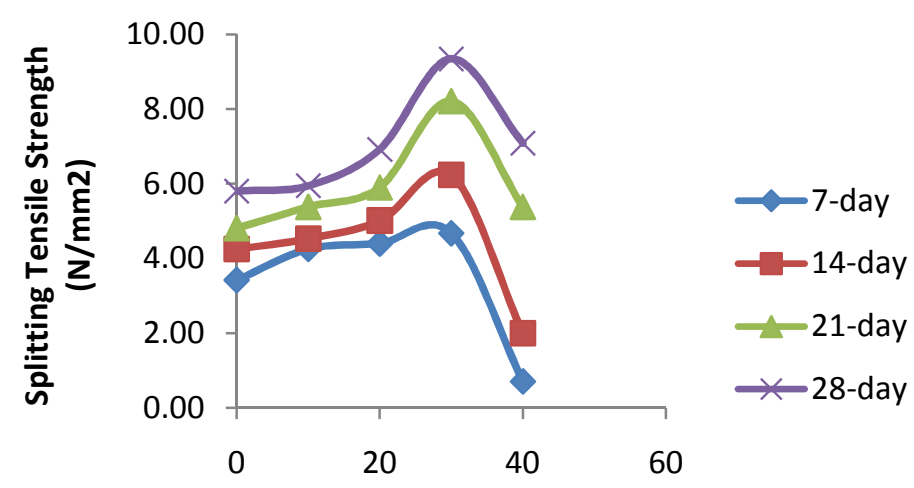

Cement replacement with polyvinyl waste (\%

Figure 9: Effect of Polyvinyl Waste on the Splitting Strength of the Specimens

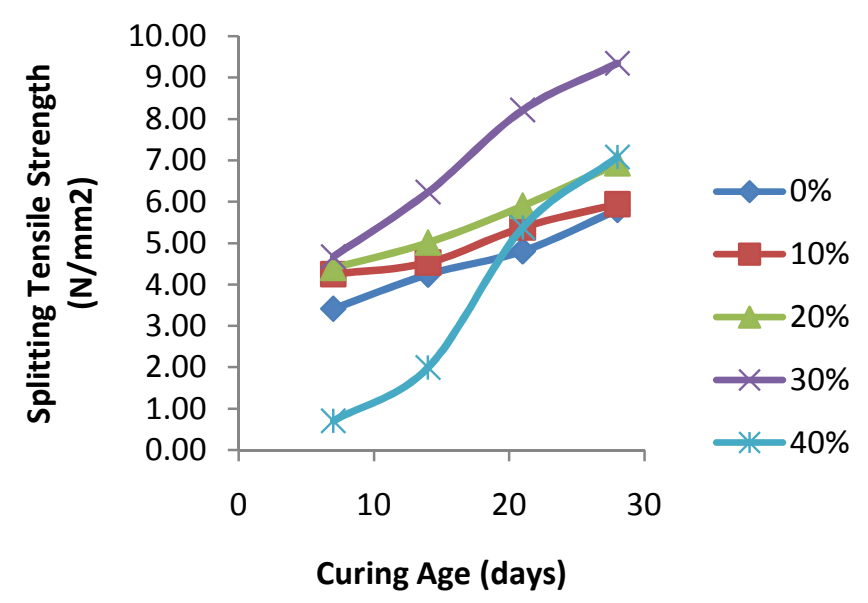

Figure 10: Variation of Tensile Strength with Curing Age

Table 5: 28-Day Ratio of Splitting Strength to Compressive Strength

\begin{tabular}{cccc}
\hline $\begin{array}{c}\text { \% } \\
\text { PWP }\end{array}$ & $\begin{array}{c}\text { Splitting } \\
\text { Strength }\left(\mathrm{N} / \mathrm{mm}^{2}\right) \\
{[\mathrm{B}]}\end{array}$ & $\begin{array}{c}\text { Compressive } \\
\text { strength } \\
\left(\mathrm{N} / \mathrm{mm}^{2}\right)[\mathrm{C}]\end{array}$ & $\begin{array}{c}\text { Strength } \\
\text { Ratio } \\
(\mathrm{B} / \mathrm{c})\end{array}$ \\
\hline 0 & 5.8 & 18.08 & 0.32 \\
10 & 5.94 & 18.22 & 0.33 \\
20 & 6.92 & 19.41 & 0.37 \\
30 & 9.34 & 17.76 & 0.53 \\
40 & 7.08 & 15.48 & 0.48 \\
\hline
\end{tabular}


At all the replacement level considered, the ratios were higher than the values obtained for the control specimens. This is an indication of improved tensile performances as the percent cement replacement with polyvinyl waste increased.

\section{CONCLUSIONS}

From the results of this investigation, the following conclusions are made:

1) The use of polyvinyl waste powder (PWP) in concrete resulted in concrete with density in the conventional range values.

2) Polyvinyl waste powder (PWP) increased the setting times - initial and final - of paste incorporating it.

3) The inclusion of polyvinyl waste powder (PWP) has a dehydrating effect on the mix, resulting in leaner mix and progressive reduction in workability as the percent replacement is increased.

4) Polyvinyl is pozzolanic in character having satisfied the strength activity index condition set by [27]

5) Replacing cement with Polyvinyl waste up to $20 \%$ and up to $30 \%$ resulted in higher compressive strength and higher splitting strength respectively in relation to the control.

\section{REFERENCES}

[1] Metha, P. K. and Monterro, P. J. M. (2008) "Concrete and Environment". Concrete: Microstructure and properties www.ce.berkerly.edu (assessed 7 - 3 2014).

[2] Naik, R. N. (2008) "Sustainability of Concrete Construction". Practice Periodical on Structural Design and Construction - American Society of Civil Engineers, pp. 98 - 103

[3] Franklin, A. (2009) "Nigeria: Minister Forecast Selfsufficiency in Cement Production". The Vanguard Newspapers, 26th November, 2009.

[4] Falade, Funso, Ikponmwosa, Efe., and Fapohunda, Chris. (2013) "Low-Cost Construction Through The Use Of Pulverized Bone Foamed Aerated Concrete (PB-FAC)". The International Institute for Science, Technology, and Education: Journal of Civil and Environmental Research, 3 (10), 108 - 113.

[5] Baboo, R., Naushad, H., Abhishek, K., Tabin, R., and Dugai, S. (2011) "Influence of Marble Powder/Granule in Concrete Mix". International Journal of Civil and Structural Engineering, Vol. 1, No. 4, pp. 45 - 57.

[6] Sheike, V. M. Pawde, P. Y. and Shrivastava, R. R. (2012) "Effect of Marble Powder with and without Silica Fume on Mechanical Properties of Concrete". Journal of Mechanical and Civil Engineering, Vol. 1, Issue 1, pp. 40 - 45.
[7] Marthong, C. (2012) "Sawdust Ash as Partial Replacement of Cement". Research and Application, Vol. 2, No. 4, pp. 1980 - 1985.

[8] Udoeyo, F. and Dashibil, P. (2002) "Sawdust Ash as Concrete Material". Journal of Materials in Civil Engineering, Vol.14, No. 2, pp. 173 - 176.

[9] Opeyemi and Makinde (2012) "The Suitability of Partial Replacement of Cement with Rice Husk Ash and Bone Powder in Concrete Structures". International Journal of Emerging Technology and Advanced Engineering, Vol. 2, Issue 9, pp. 67 - 76.

[10] Salau, M. A. and Olonade, K. A. (2011) "Pozzolanic Potentials of Cassava Peel Ash". Journal of Engineering Research, Vol. 16, No. 1, pp. 10 - 20.

[11] Falade, Funso, Ikponmwosa, Efe., and Fapohunda, Christopher (2013b)"A Study on the Compressive and Tensile Strength of Foamed Concrete Containing Pulverized Bone as a Partial Replacement of Cement".University of Pakistan Journal of Engineering and Applied Science, 13, 82 93.

[12] Falade, F., Ikponmwosa, E., and Fapohunda, C. (2012) "Potential of Pulverized Bone as a Pozzolanic Material". International Journal of Scientific and Engineering Research, 3 (7), 1 - 6.

[13] Falade, Funso, Ikponmwosa, Efe, and Fapohunda, Christopher. (2014) "Flexural Performance Of Foamed Aerated Concrete Containing Pulverized Bone As Partial Replacement Of Cement". Maejo University: Maejo International Journal of Science and Technology, 8(1), 20 - 31.

[14] Fapohunda, Christopher, Oyelade, Akintoye and Ajibade, Charles (2014) "Some Properties of Concrete Containing Roofing Sheet Waste as Partial Replacement of Cement". American Journal of Material Science. Vol. 4, No. 1, pp. 18 - 24.

[15] CHEJ - CENTER FOR HEALTH, ENVIRONMENT AND JUSTICE (2004) "PVC - The Poison Plastic, Health Hazards, and the Looming Waste Crisis".www.chej.org (assessed 7 - 3 - 2014)

[16] Thornton, J. (2002) "Environmental Impacts of Polyvinyl Chloride Building Materials". Healthy Building Network, Washington, D. C.

[17] NIS 444 (2003). Standard for Cement. Standard Organization of Nigeria, Lagos.

[18] BS 12 (1996). "Specification for Portland Cement". British Standard Institution, London.

[19] BS EN 12350: Part 2 (2000). Method for Determination of Slump. British Standards Institution, London.

[20] BS EN 12350: Part 6 (2000). Method for Determination of Density. British Standards Institution, London. 
[21] BS EN 12390-3 (2009). Testing Hardened Concrete: Compressive Strength of Test Specimens. British Standard Institution, London.

[22] BS EN 12390-6 (2009). Testing Hardened Concrete. Tensile Splitting Strength of Test Specimens. British Standard Institution, London.

[23] Mindess, S.; Young, J. and Darwin, D. (2003). Concrete. Pearson International Education, $2^{\text {nd }}$ Edition.

[24] Neville, A. M. (2003). Properties of Concrete. Pearson Education, $4^{\text {th }}$ Edition.
[25] ACI Committee 116 (2000). "Cement and Concrete Terminology, " ACI 116R-00, ACI Manual of Concrete Practice. Detroit, MI.

[26] Falade, F. Ikponmwosa, E. E. and Arogundade, A. (2011) "Investigations of Some Structural Properties of Foamed Aerated Concrete". Journal of Engineering Research, Vol. 16, No. 1, pp. $67-81$.

[27] ASTM C 618-08 - Standard Specification for Coal Fly Ash and Raw or Calcined Natural Pozzolan for Use in Concrete, ASTM International, PA. 